\title{
Characterization and evaluation of heavy metal tolerance of bacterial species from soil of waste area near Riyan steel rolling mills, Muzaffarnagar, India
}

\author{
Satyajeet Khare*1, Niaz Ahmed ${ }^{1}$, Shailja Pant ${ }^{1}$ and $\operatorname{Ram}_{\text {Das }}{ }^{2}$ \\ ${ }^{1}$ Department of Microbiology, Dolphin PG Institute of Biomedical and Natural Sciences, Manduwala, Dehradun-247008 \\ (Uttrakhand), INDIA \\ ${ }^{2}$ National JALMA Institute for Leprosy \& Other Mycobacterial Disease, Tajganj, Agra (U.P.), INDIA \\ *Corresponding author. E-mail: satyajeet18@gmail.com
}

\begin{abstract}
The present study observed a variety of microorganisms from the soil of the waste area near Riyan Steel Rolling Mills, Muzaffarnagar. Among the microorganisms, 10 isolates of Bacillus subtilis, Pseudomonas aeruginosa and Staphylococcus aureus showed great potential against detrimental heavy metals like $\mathrm{Hg}, \mathrm{Pb}, \mathrm{Zn}$. Out of these 10 isolates, only 2 isolates of Bacillus subtilis (N1A2, N1P2), one isolates of $P$. aeruginosa N1A4 and one isolates of $S$. aureus A1N3 showed tremendous tolerance against various heavy metals. Bacillus subtilis N1A2 showed $15 \times 10^{9} \mathrm{cfu} / \mathrm{ml}$ in $100 \mu \mathrm{g} / \mathrm{ml}$ of $\mathrm{HgCl}_{2}$ whereas $B$. subtilis $\mathrm{N} 1 \mathrm{P} 2$ showed $15 \times 10^{9} \mathrm{cfu} / \mathrm{ml}$ in $400 \mu \mathrm{g} / \mathrm{ml}$ of zinc acetatate. Similarily Pseudomonas aeruginosa N1A4 showed $11 \times 10^{9} \mathrm{cfu} / \mathrm{ml}$ in $150 \mu \mathrm{g} / \mathrm{ml}$ of lead acetate. Staphylococcus aureus A1N3 showed great resistance towards $450 \mu \mathrm{g} / \mathrm{ml}$ of zinc sulphate and maintain their growth up to $7 \times 10^{9} \mathrm{cfu} /$ $\mathrm{ml}$. strains were identified as Bacillus subtilis, Pseudomonas aeruginosa and Staphylococcus aureus on the basis of their morphological, physiological and biochemical and compared with their standard MTCC strains.
\end{abstract}

Keywords: Heavy metals, CFU, Bacillus subtilis, Pseudomonas aeruginosa, Staphylococcus aureus

\section{INTRODUCTION}

The term heavy metal refers to any metallic chemical element that has a relatively high density and toxic to human health, animal and ecosystem at low concentrations. Heavy metals are natural components of the earth's crust and cannot be degraded or destroyed. To a small extent they enter our bodies via food, drinking water and air. Certain heavy metals in traces such as copper, selenium, zinc are essential to maintain the metabolism of the human system. However, at higher concentration they can lead to poisoning. Heavy metals may enter in the human system through a variety of ways but most commonly through contaminated water as well as through edible vegetables etc. which are cultivated nearly the area where industrial effluents contaminating heavy metals are being discharged or irrigated. Nriagu and Pacyna, (1998) showed that the activity of man have become the decisive factor in the global cycle, after comprehensive stocktaking of worldwide emission of metals in the most important environmental fields. Heavy metals like $\mathrm{Hg}$ and $\mathrm{Pb}$ are highly toxic, but many other metals are also of concern, including $\mathrm{As}, \mathrm{Br}, \mathrm{Cd} \mathrm{Cr}, \mathrm{Cu}$, $\mathrm{Ni}, \mathrm{Mn}$, Se and Zn.

Mercury is one of the major pollutants in the environment which is highly toxic and causes adrenal dysfunction, allergy, alopecia, anorexia, anxiety, birth defects, blushing, brain damage, cataracts, cerebral palsy, poor coordination
/ jerky movements, deafness, depression, dermatitis, discouragement, dizziness, drowsiness, eczema, emotional disturbances, excess saliva, fatigue, gum bleeding and soreness, headaches (band type), hearing loss, hyperactivity, hypothyroidism, forgetfulness, immune dysfunction, insomnia, irritability, joint pain, kidney damage, loss of self-control, memory loss, mental retardation, metallic taste, migraines, nervousness, nerve fiber degeneration, numbness, pain in limbs, rashes, retinitis, schizophrenia, shyness, speech disorders, suicidal tendencies, tingling, tremors (eyelids, lips, tongue, fingers, extremities), vision loss, and weakness (Onalaja and Claudio, 2000).

The ingestion of $\mathrm{Zn}$ at higher level than recommended level can have adverse effects on health. If doses 10-15 times higher than these recommended are taken by mouth, even for a short time, the stomach cramps, nausea and vomiting may occur. Ingesting high levels for several months may cause anaemia, damage to the pancreas, and decreased levels of high-density lipoprotein (HDL) cholesterol (USPHS, 1997). Lead poisoning has been known for centuries. Lead exposure can cause seizures, mental retardation, and behavioral disorders. The threat that heavy metals pose to human and animal health is aggravated by their low environmental mobility, even under high precipitations, and their long term persistence in the environment. Lead one of the more persistent metals, has been estimated to present in soil (Sobolev 
and Begonia, 2008).

The heavy metal resistant microorganisms have significant role in the treatment of hazardous substances. Microbes have evolved several mechanisms to tolerate the presence of heavy metals. These mechanisms include the efflux of metal ions outside the cell, accumulation and complexation of metal ions inside the cell and reduction of the heavy metal ions to a less toxic state. The detoxifying ability of these resistant microorganisms can be manipulated for bioremediation of heavy metals. Industrial effluents having heavy metals resistant can be treated with these microorganisms by the processes like of the environment bio sorption, bio accumulation and bio precipitation. This study was aimed to isolate and identify heavy metal resistant bacteria from soil of Steel Rolling Mills Meerut Road, Muzaffarnagar, India.

\section{MATERIALS AND METHODS}

Sample collection: The tested soil samples were collected in polythene bags from waste area near M/S Riyan Steel Rolling Mills Meerut Road, Muzaffarnagar where all the waste material is settled.

Preparation of Heavy metals concentration: For the isolation of heavy metals resistant bacteria, Nutrient agar medium (NAM) incorporated with heavy metals like Mercuric chloride, Lead acetate, Zinc sulphate, Zinc acetate were prepared separately. The concentration of each heavy metal ranged from $25-450 \mathrm{ì} \mathrm{g/ml} \mathrm{of} \mathrm{the} \mathrm{medium.}$ For that, stock solution of different heavy metals (600 ì $\mathrm{g} / \mathrm{ml}$ ) was prepared by using formula V1-S1=V2-S2 . Working solution of different heavy metals ranging from (25-450 ì g/ml) was prepared from this stock solution by adding specific amount in autoclaved nutrient agar media. All the heavy metals were added after autoclaving; due to there may be chance to degrading and volatilization for its salt nature (Hughes and Poole, 1991).

Isolation of heavy metal resistant bacteria: Isolation of bacteria was performed by using the method of Rajbhansi (2008). For that, $10 \mathrm{~g}$ of soil sample were transferred to $100 \mathrm{ml}$ sterile distilled water and mixed thoroughly by shaking the flask for 5 minutes on a rotary shaker. Serial dilutions of the suspension were made upto $10^{-1}$ to $10^{-6}$ using sterile distilled water. After preparation of different concentration of heavy metals with nutrient agar media, a sample of $0.1 \mathrm{ml}$ from the appropriate dilutions was spread over cooled agar medium in petriplates, each agar plates contained four dilution of soil sample $\left(10^{-4}, 10^{-6}\right.$, $10^{-8}$ and $10^{-10}$ ) and incubated at $37^{\circ} \mathrm{C}$ for $24-72 \mathrm{~h}$. After the incubation period the plates were observed for any kind of growth on the media.

The isolated and distinct colonies on media were subculture repeatedly after different time interval. The pure culture was kept in slant and stored in refrigerator at $4 \mathrm{C}$ for further study. All the results were noted in triplicates. All strains were identified on the basis of morphology and biochemical tests according to Berge's manual of systemic bacteriology.

Characterization of heavy metal Resistant Bacteria: The selected bacterial isolates were streaked on nutrient agar plates and colony color, form, elevation and colonial margins were recorded. Standard cultures of B. subtilis MTCC 441 Pseudomonas aeruginosa MTCC 4676 and Staphylococcus aureus MTCC 3164 were procured from Microbial Type Culture Collection Center (MTCC), Institute of Microbiological Techniques (IMTECH), Chandigarh, India.

Physiological and biochemical characterization of the bacterial isolates were carried out according to Bergey's Manual of determinative bacteriology (Holt et al., 1994) and comparing with the standard isolates.

\section{RESULTS AND DISCUSSION}

The morphological characters of the isolated colonies such as colony growth, colony color, pigmentation in substrate, elevation and colonial margins, shape were similar with MTCC strains of Bacillus subtilis and Pseudomonas aeruginosa and Staphylococcus aureus. In the present study, eight isolates of Bacillus, one isolate of Pseudomonas aeruginosa and one isolates of Staphylococcus aureus were isolated from soil of iron steel factory.

Screening of isolates was done on the basis of tolerance to Heavy metals. B. subtilis isolates were abbreviated as N1A1, N1A2, N1A3, N1P1, N1P2, N1P3, A1N1 and A1N2. $P$. aeruginosa was abbreviated as N1A4 and S. aureus was abbreviated as A1N3. All the strains showed vigorous growth at different concentrations, e.g. Mercury chloride 25 ì $\mathrm{g} \mathrm{ml}^{-1}$, Lead acetate $100 \mathrm{ì} \mathrm{g} \mathrm{ml}^{-1}$, Zinc sulphate $250 \mathrm{ì} \mathrm{ml}^{-1}$, Zinc acetate $250 \mathrm{ì} \mathrm{g} \mathrm{ml}^{-1}$, but growth (CFU/ml) decreased with the higher concentrations of heavy metal e.g. mercury chloride $100 \mathrm{ìg} \mathrm{ml}^{-1}$, Lead acetate $150 \mathrm{ì} \mathrm{g} \mathrm{ml}^{-}$ ${ }^{1}$, Zinc sulphate $450 \mathrm{ì} \mathrm{g} \mathrm{ml}^{-1}$ and Zinc acetate $400 \mathrm{ì} \mathrm{m} \mathrm{ml}^{-1}$ shown in the Table 1 . The decreased growth at higher concentrations revealed that heavy metal Mercury chloride, Lead acetate, Zinc sulphate, Zinc acetate affects the growth of bacteria.

Cell elongation, cell division, and cell metabolism are affected under stress environmental condition. In liquid medium the strains could resist low concentrations, because in the liquid medium as compared to solid medium, the bacterial cells are in clear surrounded on all the sides with metal ions, while in solid medium the metal ions bound with the components of the agar medium.

$\mathrm{Hg}$ is extremely toxic to both animal and plants at low concentrations. Therefore any elevation could have a deleterious effect on any exposed biota (Sobolev and Begonia, 2008). Pahan et al. (1995) reported Bacillus pasteurii DR2, a broad-spectrum Hg-resistant bacterial 
Table 1. Level of heavy metals resistance and growth $(\mathrm{CFU} / \mathrm{ml})$ of isolates.

\begin{tabular}{|c|c|c|c|c|}
\hline Metal & $\begin{array}{c}\text { Concentration } \\
\mu \mathrm{g} / \mathrm{ml}\end{array}$ & Dilution factor & CFU/ml & Strain No. \\
\hline Mercuric chloride & $\begin{array}{c}00 \\
25 \\
50 \\
100 \\
\end{array}$ & $10^{-8}$ & $\begin{array}{c}300 \times 10^{11} \pm 15.27 \\
31 \times 10^{9} \pm 1 \\
27 \times 10^{9} \pm 4.0 \\
15 \times 10^{9} \pm 4.0\end{array}$ & N1A2, N1A2,N1A3 \\
\hline Lead acetate & $\begin{array}{c}00 \\
50 \\
100 \\
150\end{array}$ & $10^{-8}$ & $\begin{array}{c}300 \times 10^{11} \pm 20 \\
50 \times 10^{9} \pm 3.21 \\
33 \times 10^{9} \pm 1.5 \\
11 \times 10^{9} \pm 2\end{array}$ & N1A4 \\
\hline Zinc acetate & $\begin{array}{c}00 \\
100 \\
250 \\
400 \\
\end{array}$ & $10^{-8}$ & $\begin{array}{c}300 \times 10^{11} \pm 5 \\
99 \times 10^{9} \pm 5.13 \\
76 \times 10^{9} \pm 3.0 \\
15 \times 10^{9} \pm 4.0 \\
\end{array}$ & N1P1, N1P2, N1P3 \\
\hline Zinc sulphate & $\begin{array}{c}00 \\
100 \\
250 \\
400\end{array}$ & $10^{-8}$ & $\begin{array}{c}300 \times 10^{11} \pm 7.6 \\
95 \times 10^{9} \pm 6.1 \\
69 \times 10^{9} \pm 5.0 \\
17 \times 10^{9} \pm 3.0\end{array}$ & $\mathrm{~A} 1 \mathrm{~N} 1, \mathrm{~A} 1 \mathrm{~N} 2, \mathrm{~A} 1 \mathrm{~N} 3$ \\
\hline
\end{tabular}

strain, exhibited delayed sporulation. Sporulation is the natural character of Bacillus which favoure the growth even under stress conditions. Delayed sporulation of $B$. pasteurii DR2 in the presence of $\mathrm{HgCl}_{2}$ might be the result of induction and expression of mer operon by $\mathrm{HgCl}_{2}$ (Silver and Misra 1988) and suppression of sporulation genes including genes for an RNA polymerase ó factor and a putative D-carboxypeptidase (Wu et al., 1992). Probably these genes are expressed leading ultimately to sporulation when the concentration of $\mathrm{HgCI}_{2}$ in the sporulating medium decreases.

In the present study, Bacillus subtilis N1A2 showed $15 \times 10^{9} \mathrm{cfu} / \mathrm{ml}$ in $100 \mu \mathrm{g} / \mathrm{ml}$ of $\mathrm{HgCl}_{2}$ whereas B. subtilis $\mathrm{N} 1 \mathrm{P} 2$ showed $15 \times 10^{9} \mathrm{cfu} / \mathrm{ml}$ in $400 \mu \mathrm{g} / \mathrm{ml}$ of zinc acetatate (Table 1 and 2). Pahan et al. (1995) indicated that sporeforming mercury-resistant bacteria may serve as a better mercury-scavenger in the adverse toxic environments. Pahan et al. (1995) reported Bacilli committed to sporulation were more efficient in tackling nutritional and environmental stress conditions. Exposure to high enough levels of metallic, inorganic or organic $\mathrm{Hg}$ can permanently damage these organs (USPHS 1997). Environmental legislation exists in abundance to control and monitor $\mathrm{Hg}$ discharges (e.g. 75/437/EEC; 82/176/EEC; 84/156/EEC; 85/613/EEC; 78/319/EEC). Hg concentrations associated with clean sediments are extremely low, with levels ranging from $0.03 \mathrm{mg} / \mathrm{kg}$ to $0.2 \mathrm{mg} / \mathrm{kg}$ (Wuertz and Mergeay, 1997).

Similarily Pseudomonas aeruginosa N1A4 showed $11 \times 10^{9}$ $\mathrm{cfu} / \mathrm{ml}$ in $150 \mu \mathrm{g} / \mathrm{ml}$ of Lead acetate (Tables 1 and 2). Chandrasekaran and Lalithakumari (1998) reported fastgrowing Pseudomonas fuorescens CAS102, isolated by enrichment technique from polluted soil, effectively utilized morpholine as the energy source. The heavy metal resistant bacteria have the tendency to convert these organic heavy metal salts into elemental form by using different mechanisms. Most of isolates carries plasmids for resistance to heavy metals (Deeb, 2009). Removal of biohazards by using microbes is very cost effective method in comparison to other methods.

In this study, Staphylococcus aureus A1N3 showed great resistance towards $450 \mu \mathrm{g} / \mathrm{ml}$ of Zinc sulphate and maintain their growth up to $7 \times 10^{9} \mathrm{cfu} / \mathrm{ml}$ (Table 1 and 2). Out of these 10 isolates, only 2 isolates of Bacillus subtilis (N1A2, N1P2), one isolates of $P$. aeruginosa N1A4 and one isolates of $S$. aureus A1N3 showed tremendous tolerance against various heavy metals.

However, ten isolates were chosen to study for their morphological, physiological and biochemical characteristics. Mercury chloride resistant isolates were N1A1, N1A2, N1A3; Zinc acetate resistant isolates were N1P1, N1P2, N1P3 whereas Zinc sulphate resistant isolates were $\mathrm{A} 1 \mathrm{~N} 1, \mathrm{~A} 1 \mathrm{~N} 2$ and $\mathrm{A} 1 \mathrm{~N} 3$ and lead acetate resistant isolates was N1A4. Morphological characteristics of isolates showed circular entire margin, gram positive, rod shaped and gram positive cocci, where as some are off white, circular, entire margin, gram negative rod shaped (Table 3).

Table 2. Level of heavy metals resistance at highest concentration of selected isolates.

\begin{tabular}{lccl}
\hline Resistant & $\begin{array}{c}\text { Highest concentration } \\
(\boldsymbol{\mu g} / \mathbf{m l})\end{array}$ & Bacteria & Strains \\
\hline Lead acetate & 150 & Pseudomonas aeruginosa & N1A4 \\
Zinc sulphate & 450 & Staphylococcus aureus & A1N3 \\
Mercuric chloride & 100 & Bacillus subtilis & N1A2 \\
Zinc acetate & 400 & Bacillus subtilis & N1P2 \\
\hline
\end{tabular}




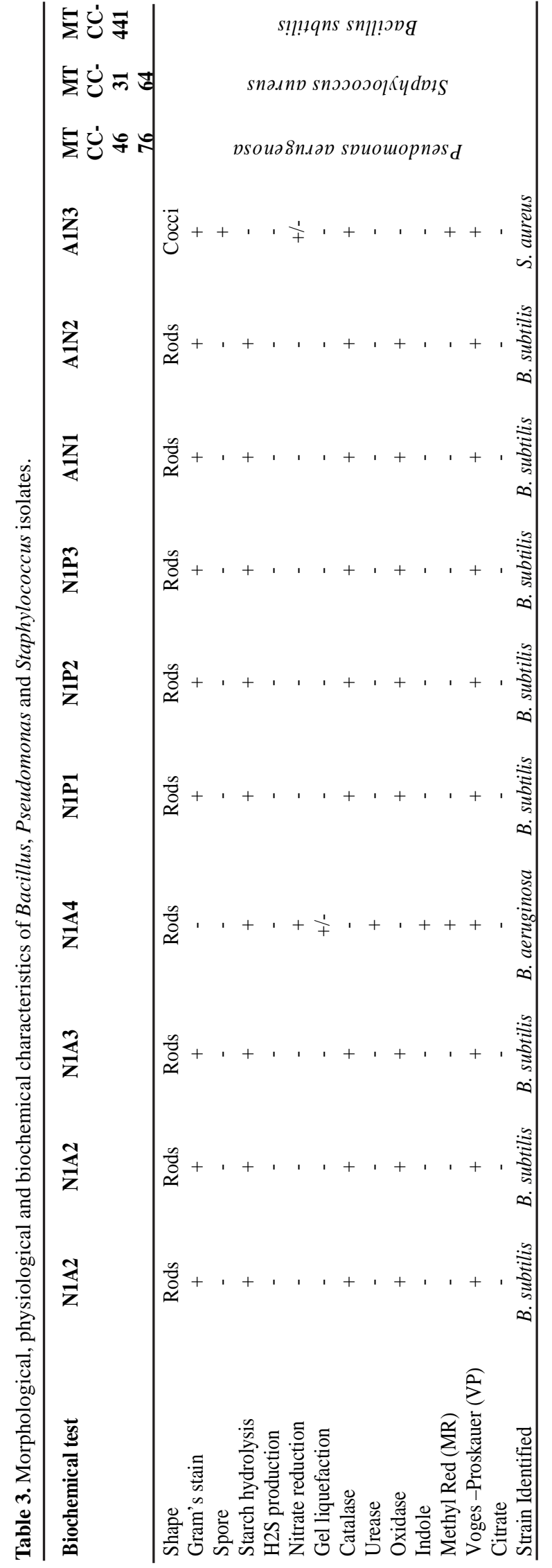

Strains were compared for their characteristics with standard strains of $B$. subtilis MTCC 441, Pseudomonas aeruginosa MTCC 4676 and Staphylococcus aureus MTCC 3164. Biochemical pattern of resistant isolates were showed that all strains except A1N3 was positive for amylase production, oxidase production, Urease production, Indole production, Methyl red, Voges Proskauer, and negative for $\mathrm{H}_{2} \mathrm{~S}$ production, gel liquefaction, catalase, citrate utilization and nitrate reduction test while the strain $\mathrm{A} 1 \mathrm{~N} 3$ shown positive results for Catalase, Voges Proskauer and Methyl Red, Nitrate reduction. Resistant strain N1A4 isolated from Lead acetate was shown starch hydrolysis, Gel liquefaction, Urease production, Indole production, , methyl red positive, Voges Proskauer positive, citrate utilization positive, and Nitrate reduction test positive but negative for $\mathrm{H} 2 \mathrm{~S}$ production, catalase.

Based on morphological, physiological and biochemical characters strains N1A1, N1A2, N1A3, N1P1, N1P2, N1P3, was found similar to that of MTCC 441 which showed small; round; white; opaque; and abundant with 2-4 mm diameter colonies, motile, aerobic, gram-positive, straight rods with round ends and endospore former. Strain N1A4 was found similar to that of Pseudomonas aeruginosa MTCC 4676 whereas A1N1, A1N2, A1N3 were found similar to that of Staphylococcus aureus MTCC 3164 (Table 3).

Therefore, present study indicated that, the most abundant type of bacteria resistant to lead is Pseudomonas aeruginosa and Staphylococcus aureus, where as in case of Mercuric chloride, Zinc acetate and Zinc sulphate are mostly Bacillus subtilis.

\section{REFERENCES}

Chandrasekaran, S. and Lalithakumari, D. (1998). Plasmidassisted morpholine degradation by Pseudomonas fluorescence CAS 102. World Journal of Microbiology \& Biotechnology, 14: 7-10.

Deeb, B. E. (2009). Plasmid mediated tolerance and removal of heavy metals by Enterobacter sp. American Journal of Biochemistry and Biotechnology, 5 (1): 47-53

Holt, J.G., Krieg, N.R., Sneath, P.H.A., Staley, J.T., and Williams, S.T. (1994). In, Bergey's manual of Determinative Bacteriology. Williams and Wilkins Press, Baltimore, U.S.A. Hughes, M.N. and Poole, R.K. (1991). Metal speciation and microbial growth, the hard and soft facts. Journal of General Microbiology, 137: 725-734.

Nriagu, J.O. and Pacyna, J.M. (1998). Quantitative assessment of worldwide contamination of air, water and soil by trace metal, Nature 333: 134-139. Nies, D.H. (1999). Microbial heavy metal resistance. Applied Microbiology and Biotechnology, 51: 730-750.

Onalaja, A.O., Claudio L. (2000). Genetic susceptibility to lead poisoning. Environ Health Perspec., 1:23-38.

Pahan, K., Ghosh, D.K., Chaudhuri, J., Gachhui, R., Ray, S. and Mandal, A. (1995). Mercury detoxifying enzymes within 
endospores of a broad-spectrum mercury resistant bacillus pasteurii strain DR2. Journal of Bioscience, 20: 83-88.

Rajbanshi, A. (2008). Study on heavy hetal resistant bacteria in Guheswori sewage treatment plant. Our Nature, 6: 52-57.

Roane, T. M. and Kellogg, S. T. (1995). Characterization of bacterial communities in heavy metal contaminated soils. Canadian journal of Microbiology, 42: 593- 603.

Silver, S. and Misra, Ô. Ê. (1988). Plasmid mediated heavy metal resistances; Annual Review of Microbiology, 42: 717743

Sobolev D. and Begonia M. F. T. (2008). Effects of heavy metal contamination upon soil microbes: Lead-induced changes in general and denitrifying microbial communities as evidenced by molecular markers. Int. J. Environ. Res. Public Health, 5 (5): 450-456.

USPHS (1997). Toxicological profile on CD-ROM. Agency for Toxic Substances and Disease Registry.

Wu, J. J., Schuch, R. and Piggot, Ñ. J. (1992). Characterization of a Bacillus subtilis sporulation operon that includes genes for an RNA polymerase sigma factor and for a putative DDcarboxy-peptidase; Journal of Bacteriology, 174: 4885-4892. Wuertz, S. and Mergeay M. (1997). The impact of heavy metals on soil microbial communities and their activities. In: Van Elsas JD, Trevor's JT, Wellington EMH. (Eds). Modern Soil Microbiology Marcel Dekker, New York, pp. $607-639$. 